\title{
Predominance of Left-coiling Globorotalia truncatulinoides (d'Orbigny) between 115,000 and 50,000 yrs BP : A Latest Foraminiferal Biostratigraphic Event in the Western North Pacific
}

\author{
Xuedong $\mathrm{Xu}^{*}$, Katsunori Kimoto* and Motoyoshi Oda*
}

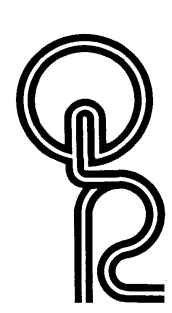

\begin{abstract}
The planktic foraminiferal species Globorotalia truncatulinoides (d'Orbigny) with left-coiling tests is distributed in limited areas in the modern world oceans, compared to that with rightcoiling tests. The left-coiling forms of this species rarely occur in Recent sediments throughout the North Pacific. However, these forms are found to have outnumbered the right-coiling forms between 115,000 and 50,000 yrs BP, based on the oxygen isotope stratigraphy in three western North Pacific cores. The predominance of the left-coiling forms probably reflects unique characteristics of the Western North Pacific Central Water and its underlying North Pacific Intermediate Water during the time span of about 65,000 years. We propose the lower and upper limits of this bioevent at respectively 115,000 and 50,000 yrs BP to be used as the latest biostratigraphic markers in the western North Pacific.
\end{abstract}

Key Words : Globorotalia truncatulinoides, coiling direction change, biostratigraphic event, Western North Pacific Central Water

\section{Introduction}

In the past ten years, many piston cores have been taken from the western North Pacific for paleoceanographic studies. Among them, cores RN89-PG3, RN87-PC4 and KH92-1 2PG (Fig. 1 and Table 1) were examined by the authors for planktic foraminifera. During the down core faunal analyses, we noticed that the shells of the species Globorotalia truncatulinoides (d'Orbigny) were almost either exclusively dextral or sinistral in any one sample, and the coiling direction kept steady during certain intervals.

We relied on $\delta^{18} \mathrm{O}$ curves for correlation of the three cores to (1) examine whether horizons of the coiling direction changes were synchronous or not, and in case they were, to (2) determine their ages.

\section{Background of the Three Studied Cores}

The three western North Pacific cores were taken from water depths of 2,255m, 2,488m and $2,683 \mathrm{~m}$ (Table 1), well above the lysocline. Cores RN89-PC3 and RN87-PC4 which were collected

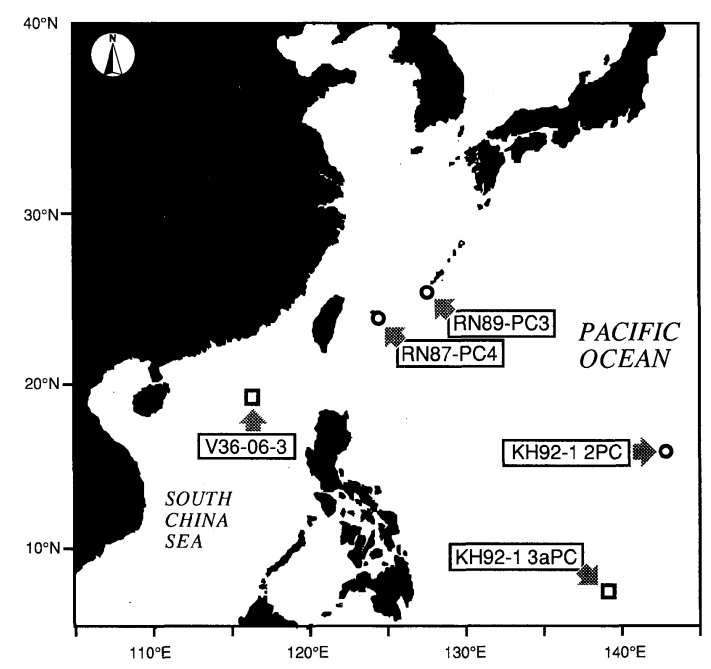

Fig. 1 Map showing locations of the piston cores used and referred in this study

Received October 25, 1994. Accepted January 21, 1995.

* Department of Earth Sciences, Faculty of Science, Kumamoto University. Kurokami 2-39-1, Kumamoto, 860. 
Table 1 Location and water depth of the piston cores used and referred in this study

\begin{tabular}{lllc}
\hline Core No. & Latitude & Longitude & Water Depth(m) \\
\hline RN87-PC4 & $23^{\circ} 50.2^{\prime} \mathrm{N}$ & $124^{\circ} 24.1^{\prime} \mathrm{E}$ & 2,488 \\
RN89-PC3 & $25^{\circ} 20.7^{\prime} \mathrm{N}$ & $127^{\circ} 28.9^{\prime} \mathrm{E}$ & 2,255 \\
KH92-1 2PC & $16^{\circ} 45.15^{\prime} \mathrm{N}$ & $143^{\circ} 03.25^{\prime} \mathrm{E}$ & 2,683 \\
KH92-1 3aPC & $08^{\circ} 00.94^{\prime} \mathrm{N}$ & $139^{\circ} 38.41^{\prime} \mathrm{E}$ & 2,830 \\
V36-06-3 & $19^{\circ} 00.5^{\prime} \mathrm{N}$ & $116^{\circ} 05.6^{\prime} \mathrm{E}$ & 2,809 \\
\hline
\end{tabular}

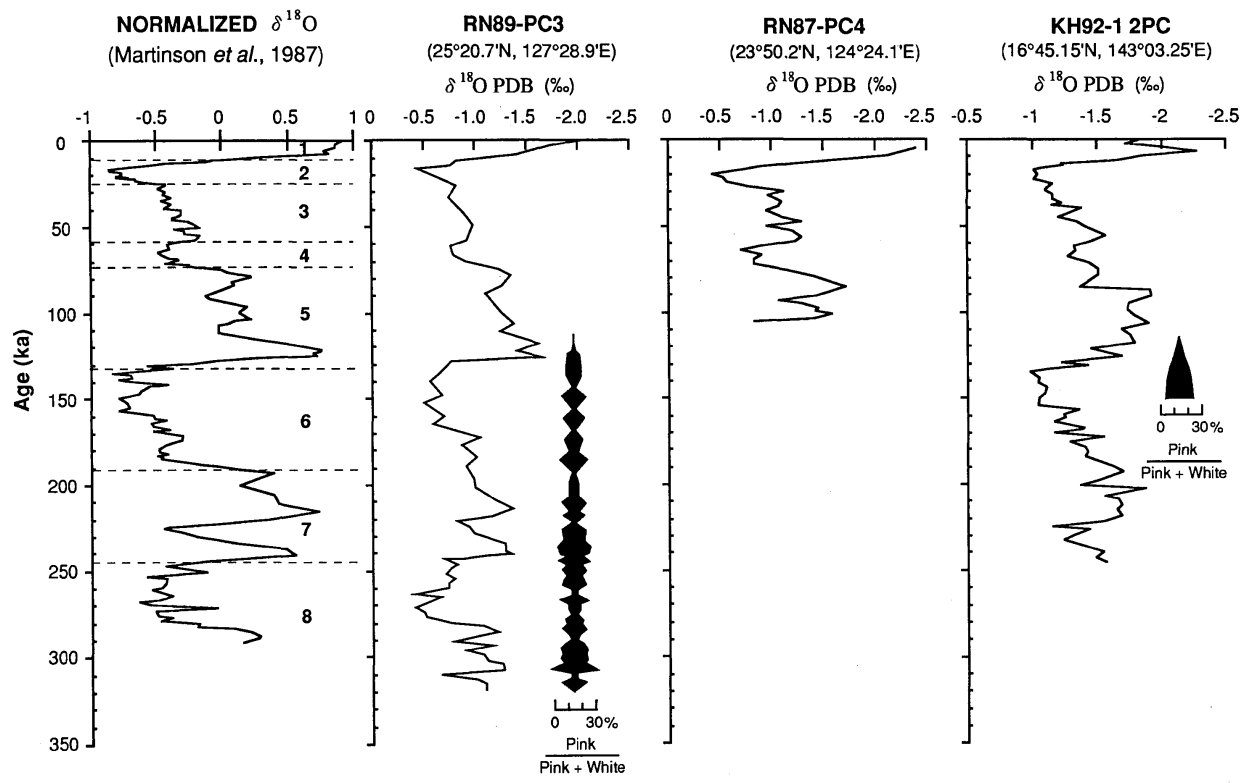

Fig. 2 Chronology of the three studied cores based on oxygen isotope stratigraphy

The $\delta^{18} \mathrm{O}$ curves are compared with that of Martinson et al. (1987). Dark shading in RN89-PC3 and KH92-1 $2 \mathrm{PC}$ is the percentage ratio of pink pigmented specimens in Globigerinoides ruber.

from the Ryukyu Trench slope, east off the southern Ryukyu Island Arc, are composed of hemipelagic silty clay and clay (Ono et al., 1989; Ono and Takagi, 1991), enriching planktic foraminifera without clear evidence for dissolution effect. Core KH92-1 2PC which was recovered from the west Mariana Rise consists of well preserved muddy calcareous ooze (Oba et al., 1993).

The chronological study of the three cores has been conducted based on the oxygen isotope stratigraphy (Ahagon et al., 1993; Matsuoka et al., 1994; Yasuda, 1994). The $\delta^{18} \mathrm{O}$ curves obtained from the studied cores can be well correlated with the normalized $\delta^{18} \mathrm{O}$ curve of Martinson et al.
(1987), and cores RN89-PC3, RN87-PC4 and KH92-1 2PC encompass the last 320,000, 105,000 and 250,000 years, respectively (Fig. 2).

\section{Coiling Direction Changes in Globorotalia truncatulinoides}

The conventional method in determining the direction of coiling was used to distinguish rightand left-coiling $G$. truncatulinoides. That is, a shell is right coiling, if, when viewed from above with the dorsal side up, the chambers have been added in clockwise direction.

Dry sediments coarser than $0.150 \mathrm{~mm}$ were used for countings of planktic foraminifera. Altogether, 


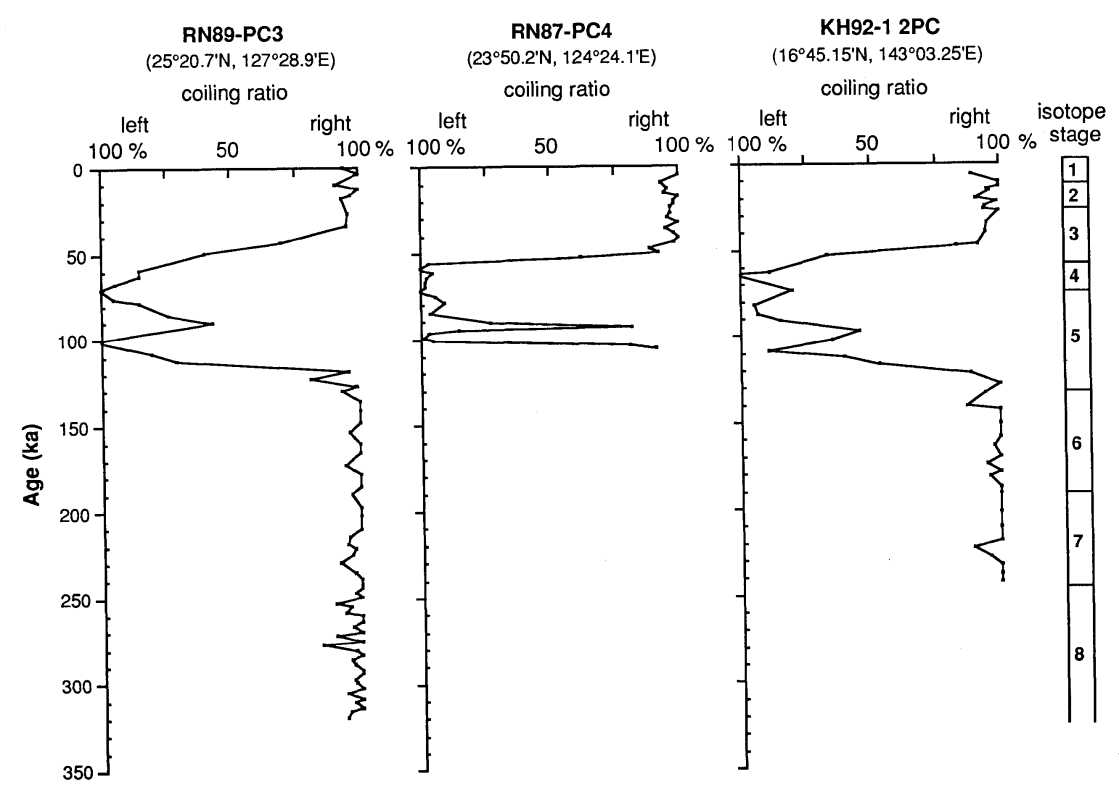

Fig. 3 Down core coiling direction changes in Globorotalia truncatulinoides in the three western North Pacific cores

The coiling ratio is expressed as the percentage of either of the coiling forms to total G. truncatulinoides.

specimens of $G$. truncatulinoides were counted in 150 sediment samples. Because of the limited amount of available calcareous sediments, the coiling ratios were based on counts of specimens as many as possible. Over 100 specimens were counted where possible, and more than 20 specimens were counted in most samples (Table 2).

Figure 3 shows the coiling direction changes in $G$. truncatulinoides at the three studied cores. Most of the interval of the last 300,000 years is predominated by the right-coiling forms. However, during a time span from the early isotope Stage 5 to early Stage 3 , the left-coiling forms outnumber the right-coiling ones in all the three studied cores. The lower- and upper- limits of the left-coiling predominance interval at respectively 115,000 and $50,000 \mathrm{yrs} \mathrm{BP}$ are almost synchronous in the three cores, based upon the oxygen isotope stage boundaries and their ages of Martinson et al. (1987) (see Figs. 2 and 3). Moreover, during the interval, a short reversal trend towards right-coiling is observed at about $90,000 \sim 95,000$ yrs BP. It seems that this sub-event can also be correlated among the three cores.

\section{Discussion}

Coiling direction ratio changes in G. truncatulinoides can be regarded as a stratigraphic indicator. The coiling ratios of $G$. truncatulinoides have been widely used for stratigraphic correlations. Bolli (1950, 1951) and Ericson and Wollin (1956) detected brief direction changes in equatorial Atlantic sequences; Emiliani (1966) also adapted them to determine necessary stratigraphy in Caribbean cores.

It is of interest that the coiling direction changes in our cores in the western North Pacific are quite different from those in the Atlantic. According to Ericson and Wollin (1956), the left-coiling predominance of $G$. truncatulinoides in the Atlantic cores is frequent and brief; some cores (those in the equatorial region) can be well correlated by the left-coiling pulses, but some cannot (those in the Carribbean). On the contrary, in the western 
Table 2 Number of specimens of left- and right-coiling Globorotalia truncatulinoides counted in each sample

\begin{tabular}{|c|c|c|c|c|c|c|c|c|c|c|c|}
\hline $\begin{array}{l}\text { RN89-PC3 } \\
\text { Depth }(\mathrm{cm})\end{array}$ & Age(ka) & \multicolumn{2}{|c|}{$\begin{array}{l}\text { G. truncatulinoides } \\
\text { (sinistral) } \\
\text { (dextral) }\end{array}$} & $\begin{array}{c}\text { KH92-1 2PC } \\
\text { Depth(cm) }\end{array}$ & Age(ka) & \multicolumn{2}{|c|}{ G. truncatulinoides } & $\begin{array}{l}\text { RN87-PC4 } \\
\text { Depth }(\mathrm{cm})\end{array}$ & Age(ka) & \multicolumn{2}{|c|}{ G. truncatulinoides } \\
\hline 0.0 & 0.0 & 2 & 32 & 12.5 & 6.1 & 2 & 17 & 10.0 & 4.8 & 0 & 24 \\
\hline 4.0 & 3.7 & 0 & 60 & 21.5 & 10.9 & 0 & 10 & 20.0 & 9.6 & 8 & 107 \\
\hline 10.0 & 9.3 & 3 & 31 & 26.0 & 12.9 & 0 & 13 & 30.0 & 13.2 & 2 & 47 \\
\hline 14.0 & 12.5 & 0 & 32 & 30.6 & 14.5 & 2 & 41 & 40.0 & 15.5 & 2 & 34 \\
\hline 20.0 & 15.4 & 1 & 32 & 35.1 & 16.2 & 1 & 24 & 50.0 & 17.9 & 0 & 60 \\
\hline 24.0 & 17.4 & 2 & 28 & 43.8 & 20.6 & 5 & 51 & 60.0 & 19.9 & 1 & 50 \\
\hline 30.0 & 26.4 & 1 & 22 & 46.1 & 21.9 & 1 & 91 & 70.0 & 22.0 & 1 & 44 \\
\hline 34.0 & 33.6 & 1 & 20 & 50.7 & 24.7 & 3 & 50 & 80.0 & 24.1 & 1 & 34 \\
\hline 40.0 & 43.1 & 13 & 30 & 53.0 & 26.0 & 4 & 61 & 90.0 & 27.0 & 2 & 57 \\
\hline 44.0 & 49.5 & 15 & 10 & 55.3 & 27.4 & 0 & 24 & 100.0 & 29.9 & 1 & 22 \\
\hline 50.0 & 59.0 & 18 & 3 & 66.8 & 34.2 & 2 & 38 & 110.0 & 32.8 & 0 & 54 \\
\hline 54.0 & 62.3 & 24 & 4 & 76.1 & 39.6 & 2 & 35 & 120.0 & 35.7 & 1 & 19 \\
\hline 60.0 & 67.3 & 20 & 1 & 87.6 & 46.4 & 4 & 45 & 130.0 & 38.6 & 1 & 47 \\
\hline 64.0 & 70.6 & 24 & 0 & 89.9 & 47.8 & 6 & 30 & 140.0 & 41.5 & 0 & 35 \\
\hline 70.0 & 75.4 & 21 & 1 & 99.1 & 53.2 & 18 & 9 & 150.0 & 44.4 & 1 & 47 \\
\hline 74.0 & 78.5 & 18 & 3 & 115.3 & 62.7 & 25 & 3 & 160.0 & 47.3 & 3 & 24 \\
\hline 80.0 & 85.1 & 26 & 9 & 117.6 & 64.1 & 18 & 0 & 170.0 & 50.2 & 4 & 46 \\
\hline 84.0 & 89.8 & 16 & 12 & 129.1 & 73.0 & 28 & 7 & 180.0 & 53.1 & 8 & 13 \\
\hline 94.0 & 100.8 & 20 & 0 & 139.1 & 82.0 & 36 & 2 & 190.0 & 56.0 & 35 & 1 \\
\hline 100.0 & 107.4 & 17 & 4 & 146.0 & 87.4 & 31 & 2 & 200.0 & 59.0 & 41 & 0 \\
\hline 104.0 & 111.8 & 20 & 8 & 150.5 & 91.0 & 23 & 4 & 210.0 & 61.7 & 22 & 1 \\
\hline 110.0 & 118.4 & 1 & 22 & 157.3 & 96.7 & 6 & 5 & 220.0 & 64.4 & 43 & 1 \\
\hline 114.0 & 122.7 & 5 & 21 & 164.1 & 102.5 & 11 & 6 & 230.0 & 67.1 & 56 & 1 \\
\hline 120.0 & 126.8 & 1 & 78 & 171.0 & 108.2 & 26 & 3 & 240.0 & 69.8 & 60 & 1 \\
\hline 124.0 & 129.2 & 2 & 26 & 175.5 & 112.1 & 9 & 6 & 250.0 & 72.6 & 30 & 0 \\
\hline 130.0 & 136.0 & 0 & 45 & 180.0 & 115.9 & 7 & 8 & 260.0 & 75.9 & 53 & 3 \\
\hline 134.0 & 140.9 & 0 & 22 & 186.9 & 121.7 & 1 & 8 & 270.0 & 79.3 & 77 & 8 \\
\hline 140.0 & 148.2 & 0 & 28 & 193.7 & 127.4 & 0 & 14 & 280.0 & 85.1 & 30 & 1 \\
\hline 144.0 & 153.1 & 1 & 22 & 200.5 & 133.2 & 1 & 16 & 290.0 & 91.0 & 36 & 13 \\
\hline 150.0 & 160.4 & 0 & 28 & 211.9 & 140.9 & 2 & 13 & 300.0 & 93.1 & 5 & 22 \\
\hline 154.0 & 165.3 & 0 & 25 & 214.1 & 142.4 & 0 & 11 & 310.0 & 95.2 & 18 & 3 \\
\hline 160.0 & 172.7 & 2 & 32 & 227.8 & 151.0 & 0 & 3 & 319.0 & 97.3 & 33 & 1 \\
\hline 164.0 & 177.6 & 0 & 23 & 238.2 & 158.3 & 0 & 19 & 330.0 & 99.4 & 116 & 1 \\
\hline 170.0 & 184.9 & 0 & 24 & 247.4 & 164.1 & 1 & 40 & 340.0 & 101.5 & 22 & 1 \\
\hline 174.0 & 189.8 & 1 & 28 & 256.6 & 169.9 & 0 & 35 & 350.0 & 103.6 & 4 & 17 \\
\hline $\begin{array}{l}180.0 \\
184.0\end{array}$ & $\begin{array}{l}197.2 \\
202.1\end{array}$ & $\begin{array}{l}0 \\
0\end{array}$ & $\begin{array}{l}23 \\
21\end{array}$ & $\begin{array}{l}263.5 \\
270.4\end{array}$ & $\begin{array}{l}174.2 \\
178.6\end{array}$ & $\begin{array}{l}1 \\
0\end{array}$ & $\begin{array}{l}18 \\
15\end{array}$ & 360.0 & 105.7 & 2 & 20 \\
\hline
\end{tabular}

Sample ages are approximate and obtained from the $\delta^{18} \mathrm{O}$ curve of each core, based on the isotope stage boundaries and their ages of Martinson et al. (1987).

North Pacific cores, predominance of the left-coiling forms is persistent in a time interval which lasted for nearly 65,000 years, and can be correlated perfectly with one another. Besides the three cores in this study, core V36-06-3 taken from the South China Sea (Fig. 1) exhibits similar coiling direction changes (Wang, 1990, Fig. 4), in which both the left-coiling predominance event and the brief reversal sub-event can be well correlated with those in this study. Therefore, we propose the predomiance of left-coiling $G$. truncatulinoides between 115,000 and 50,000 yrs BP, along with the short reversal trend towards right-coiling at 90,000 95,000 yrs BP, can be used as reliable biostratigraphic markers in the western North Pacific.

The problem is to determine the area within which the coiling direction changes in $G$. truncatuli- noides occurred. It is well known that $G$. truncatulinoides is predominantly a subtropical species inhabiting the central water masses of the oceans (Bé and Tolderlund, 1971). In the western North Pacific, the surface flow of a gyre consisting of North Equatorial, Kuroshio and its extension, and North Pacific currents forms a large water body (Fig. 5), named the Western North Pacific Central Water (WNPCW) (Bradshaw, 1959). This huge water mass lies approximately between $40^{\circ} \mathrm{N}$ and $10^{\circ} \mathrm{N}$, and has properties physically and biologically different from the farther north Subarctic Pacific Water and the farther south Equatorial Pacific Water. According to Bradshaw's study (1959) on ecology of living planktonic foraminifera in the north and equatorial Pacific, G. truncatulinoides is most abundant from approximately $40^{\circ} \mathrm{N}$ to $20^{\circ} \mathrm{N}$ 
Table 2 (continued)

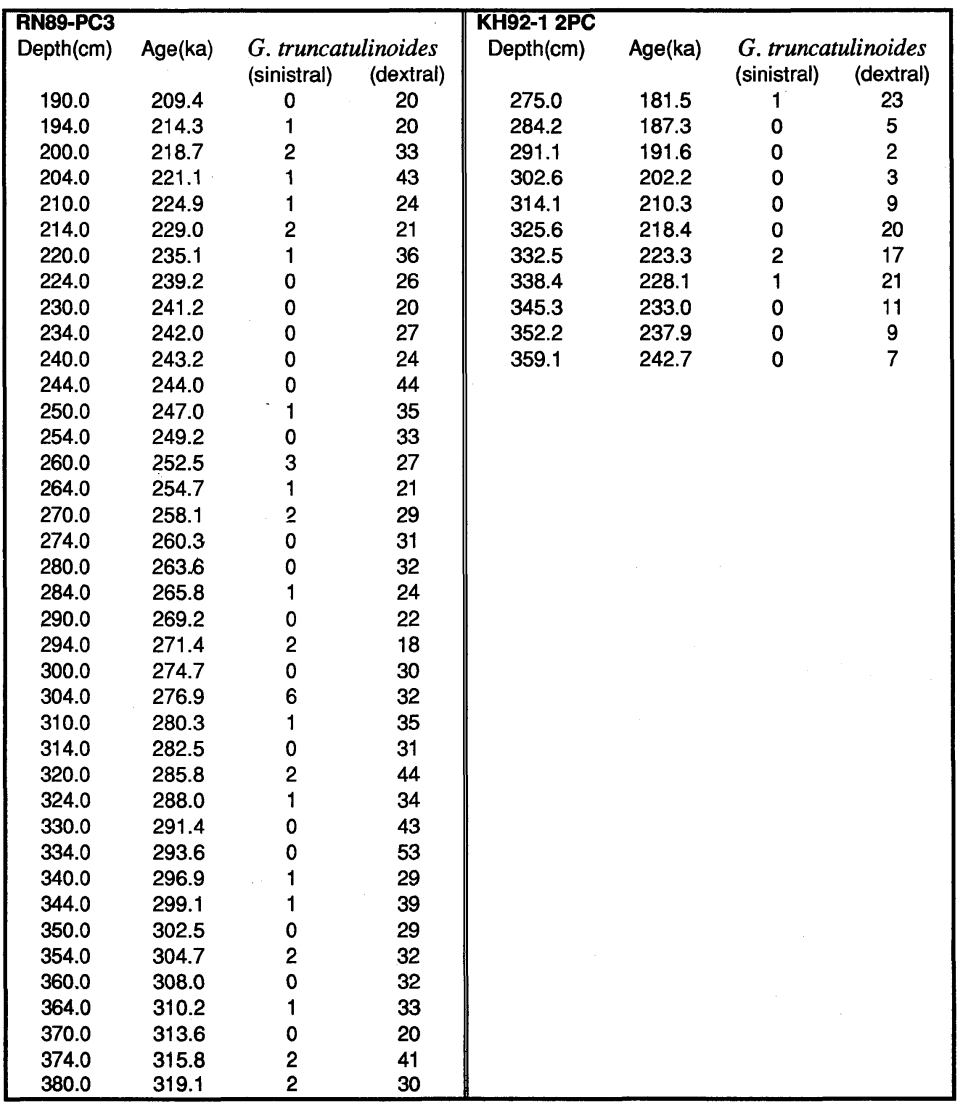

in WNPGW. The three cores studied here and the referred one taken from the South China Sea are all located within the realm affected by WNPCW. Another piston core KH92-1 3aPG (Fig. 1), which is located at $8^{\circ} \mathrm{N}$, beyond the realm of WNPCW, is also examined for planktic foraminifera, but no specimens of $G$. truncatulinoides are found. Thus, the inhabitable area of this species seems to be limited within the WNPGW.

The habitable depth of $G$. truncatulinoides in the water column makes the problem more complicated. As being pointed out by many workers, $G$. truncatulinoides lives and grows over a wide depth range, from within the surface mixed layer to over several hundred meters. That is to say this species live their life not only in the surface water but also in the underlying intermediate water. According to
Talley and Nagata (1991), the North Pacific Intermediate Water (NPIW) with minimum salinity concentrates within a zone lying approximately between $40^{\circ} \mathrm{N}$ to $20^{\circ} \mathrm{N}$ across the Pacific, and within limited areas in the western Pacific from $20^{\circ} \mathrm{N}$ to the equator. Since the NPIW lies immediately below the WNPGW, we would like to simplify the above mentioned problem by supposing that $G$. truncatulinoides' left-coiling predominance being an indicator of the time interval at $115,000 \sim 50,000$ yrs BP can only be used in regions which were influenced by the WNPCW and its underlying NPIW. To determine the exact area, however, we must study more piston cores in the western North Pacific region.

The next problem is what caused G. truncatulinoides to change their coiling ratios. The coiling 


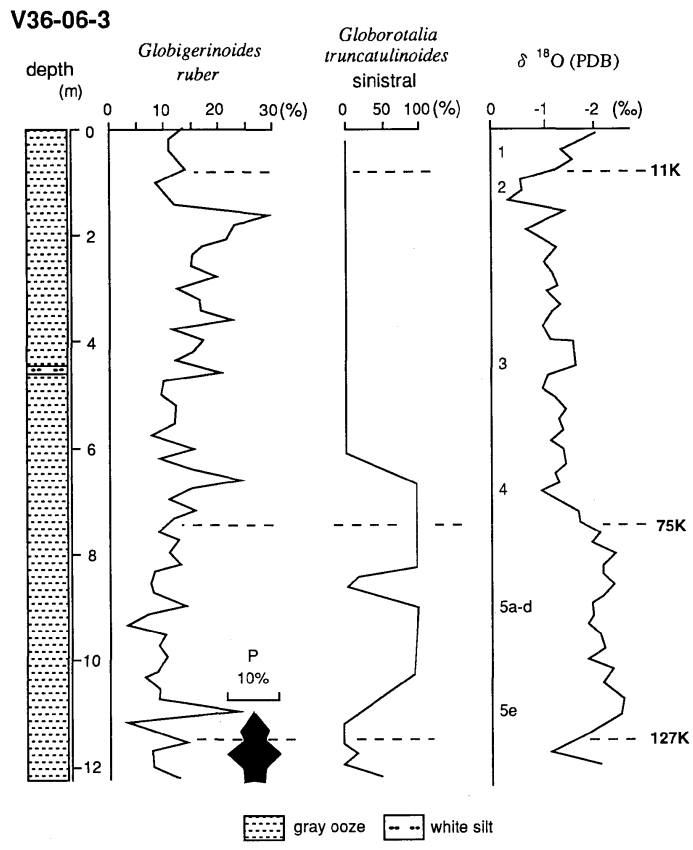

Fig. 4 Coiling direction changes in Globorotalia truncatulinoides in core V36-06-3

$\delta^{18} \mathrm{O}$ curve is that of Globigerinoides sacculifer and $\mathrm{P}$ denotes pink-pigmented tests of $G$. ruber.

Modified from Wang (1990).

direction changes of this species in Recent sediments in the world oceans have been described by many workers. Parker (1971) indicated that G. truncatulinoides showed apparently right coiling throughout the North Pacific. In the North Atlantic, two distinct right-coiling provinces are separated from each other by a central left-coiling province (Ericson et al., 1954), while in the southern hemisphere, the predominantly left-coiling forms of this species are found in colder waters and higher latitudes than the right-coiling forms (Bé and Tolderlund, 1971).

In any case, it seems that the alternative of the coiling direction has little relation to the surface temperature changes. Bé and Tolderlund (1971) pointed out that the transition from right- to leftcoiling $G$. truncatulinoides takes place abruptly in living populations in the South Atlantic and Indian Oceans. The coiling direction change of $G$. truncatu-

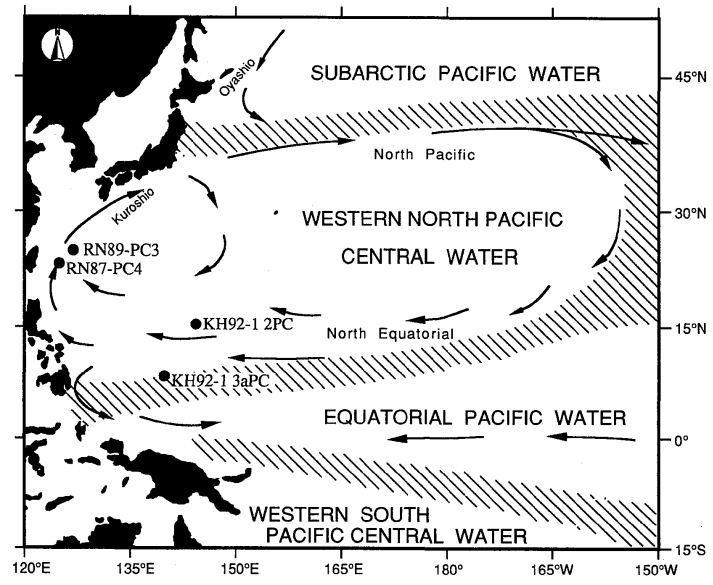

Fig. 5 Upper water masses in the Western Pacific, with emphasis on the Western North Pacific Central Water

Hatched areas are approximate boundaries of the water masses.

After Bradshaw (1959).

linoides being abrupt rather than gradual is also observed in our piston core samples : the tests are almost exclusively either left-coiling or right-coiling in most samples; a mixture of $50 \%$ left-coiling and another half right-coiling in one sample rarely occurs. Besides, the left-coiling predominance interval between 115,000 and 50,000 yrs BP should have included quite a different surface water temperatures, while the direction of coiling remained steady.

G. truncatulinoides is believed to be a very deep dwelling species (Tolderlund and Bé 1971; Hemleben et al., 1989; Lohmann and Schweitzer, 1990) at $600 \mathrm{~m}$ or more than $1,000 \mathrm{~m}$ deep in the water column. Through studying the life history of this species, Lohmann and Schweitzer (1990) indicated that it reproduces at $600 \mathrm{~m}$ deep in the water column. Their plankton tow studies showed that changes in thermocline depth appeared to be able to force changes in dominant coiling direction. In this study, we would rather not discuss the implications of the left-coiling predominance event in cores, since our knowledge on the coiling direction preference of this species is still limited. However, it seems certain that this event reflects some 
paleoceanographic changes in the deeper water column of the ocean.

The disappearance of pink-pigmented Globigerinoides ruber (d'Orbigny) at 120,000 yrs BP has been regarded as the only planktic foraminiferal datum within the last 200,000 years in the IndoPacific Oceans (Thompson et al., 1979). The predominance of left-coiling $G$. truncatulinoides, in the western North Pacific, onset just after the disappearance of pink-pigmented $G$. ruber in early isotope Stage 5, and lasted until early Stage 3. Whatever caused the coiling direction changes, we can use this event to determine the stratigraphy in regions once within the realm of the Western North Pacific Central Water and its underlying water. In other words, the coiling direction changing event will become particularly useful in the correlation of cores lacking isotopic controls or in recognizing cores missing the latest Quaternary section.

\section{Conclusion}

Predominance of left-coiling Globorotalia truncatulinoides between 115,000 and 50,000 yrs BP, along with a short reversal trend towards right-coiling at $90,000 \sim 95,000$ yrs BP, can be used as reliable biostratigraphic markers during the last 300,000 years in the western North Pacific. Oceanographic conditions in the Western North Pacific Central Water and its underlying North Pacific Intermediate Water at $115,000 \sim 50,000$ yrs BP were probably different from those of the present day.

\section{Acknowledgements}

Acknowledgements are expressed to the officers and crew of the R/V Nagasaki-maru and Hakuhomaru for their shipboard work. The available piston core samples were kindly provided by Prof. Hiroshi Ujiié University of the Ryukyus, and Prof. Tadamichi Oba, Hokkaido University. The authors are indebted to Dr. Yokichi Takayanagi, Professor Emeritus of Tohoku University, for critically reviewing the manuscript. This research was partly supported by Grant-in-Aid for Scientific Research, grant to M. Oda.

\section{References}

Ahagon, N., Tanaka, Y. and Ujiié H. (1993) Florisphaera profunda, a possible nannoplankton indicator of late Quaternary changes in sea-water turbidity at the northwestern margin of the Pacific. Marine Micropaleontol., $22: 255-273$

Bé A. W. H. and Tolderlund, D. S. (1971) Distribution and ecology of living planktonic foraminifera in surface waters of the Atlantic and Indian Oceans. B. M. Funnell and W. R. Riedel (eds.) The micropalaeontology of oceans : 105-149, Cambridge University Press

Bolli, H. (1950) The direction of coiling in the evolution of some Globorotaliidae. Cushman Found. Foram. Research Contr., $1: 82-89$

Bolli, H. (1951) Notes on the direction of coiling of rotalid foraminifera. Cushman Found. Foram. Research Contr., $2: 139-143$

Bradshaw, J. S. (1959) Ecology of living planktonic foraminifera in the north and equatorial Pacific Ocean. Cushman Found. Foram. Research Contr., 10 : 25-64

Emiliani, C. (1966) Paleotemperature analysis of the Caribbean cores P6304-8 and P6304-9 and a generalized temperature curve for the last 425,000 years. Jour. Geol., $74:$ 109-126

Ericson, D. B., Wollin, G. and Wollin, J. (1954) Coiling direction of Globorotalia truncatulinoides in deep-sea cores. Deep-sea Res., 2 : 152-158

Ericson, D. B. and Wollin, G. (1956) Correlations of six cores from the equatorial Atlantic and the Caribbean. Deep-Sea Res., 8 : 104-125

Hemleben, Ch., Spindler, M. and Anderson, O. R. (1989) Modern planktonic foraminifera. 363p, Springer-Verlag

Lohmann, G. P. and Schweitzer, P.N. (1990) Globorotalia truncatulinoides' growth and chemistry as probes of the past thermocline : 1. shell size. Paleoceanography, $5: 55$ 75

Martinson, D. G., Pisias, N. G., Hays, J. D., Imbrie, J., Moore, T. C. Jr. and Shackleton, N. J. (1987) Age dating and the orbital theory of the Ice ages : Development of a high - resolution 0 to 300,000 - year chronostratigraphy. Quat. Res., $27: 1-29$

Matsuoka, H., Kimoto, K. and Yamaguchi, S. (1994) Calcium carbonate preservation in deep-sea sediments of the north-western Pacific Ocean. Kaiyo Monthly, 26 : 425-428 (in Japanese)

Oba, T., Murayama, M., Matsuoka, H., Okamoto, T., Morita, S., Suzuki, T. and Tsukawaki, S. (1993) Sediment sampling in the western Equatorial Pacific. J. Segawa (ed.) Preliminary report of the Hakuho-Maru cruise KH92-1: 147-214, Ocean Research Institute, The Univ. of Tokyo 
Ono, T., Midorikawa, T., Yamamoto, S. and Ujiié H. (1989) Sediments taken from the sea-bottom around the southern Ryukyu Island Arc during the RN-84, 86 and -87 cruises. Bull. Coll. Sci., Univ. Ryukyus, 47 : 115-151 (in Japanese with English abstract)

Ono, T. and Takagi, U. (1991) Cruise reports of the $\mathrm{RN}-88 \sim 89$ cruises around the southern Ryukyu Island Arc and north of the Okinawa Islands, with special reference to the sediment samples. Bull. Coll. Sci., Univ. Ryukyus, $51: 57-85$ (in Japanese with English abstract)

Parker, F. L. (1971) Distribution of planktonic foraminifera in Recent deep-sea sediments. B. M. Funnell and W. R. Riedel (eds.) The micropalaeontology of oceans: 289-307, Cambridge University Press

Talley, L. D. and Nagata, Y. (1991) Oyashio and mixed water regions as a formation area of the North Pacific Intermediate Water. Umi to sora : 65-74 (in Japanese)

Thompson, P. R., Bé A. W. H., Duplessy, J. C. and Shackleton, N. J. (1979) Disappearance of pink-pigmented Globigerinoides ruber at $120,000 \mathrm{yr}$ B. P. in the Indian and Pacific Oceans. Nature, $280: 554-558$

Tolderlund, D. S. and Bé A. W. H. (1971) Seasonal distribution of planktonic foraminifera in the western North Atlantic. Micropaleontology, 17 : 297-329

Wang, P. (1990) The Ice-age China sea. Proceedings of the First International Conference on Asian Marine Geology, 1988 : 181-197, Ocean Press, Beijing

Yasuda, H. (1994) Deep water circulation change in the West Caroline Basin and surrounding areas during the last 150,000 years. Kaiyo Monthly, $26: 429-433$ (in Japanese)

\title{
11.5 万年前から 5 万年前にかけての Globorotalia truncatulinoides （d'Orbigny）の左巻き個体の優勢な層準
}

\author{
——北西太平洋域での最も新しい化石層位学的事件—
}

\author{
徐 学東 ${ }^{*} \cdot$ 木元 克典 ${ }^{*} \cdot$ 尾田 太良 ${ }^{*}$
}

\begin{abstract}
要 旨
浮遊性有孔虫の一種である Globorotalia truncatulinoides (d’Orbigny) の左巻き個体は，その右巻きの個体に比べ ると現在の世界の海洋での生息分布が限定されている. 北西太平洋域の表層堆積物中でも，左巻き個体はわずか に産出するだけである。しかしながら，北西太平洋から 得られた 3 海域の海底堆積物中で, 左巻き個体が右巻き 個体と急激に入れ替わり, 優勢になる層準が存在するこ とが今回確認された。このイベントは，安定酸素同位体

比曲線に基づいて, およそ 115,000 年前から 50,000 年 前までであることが判明した． 65,000 年間のこの種の 左巻き優勢の期間は, 北西太平洋中央水塊と北太平洋中 層水の水柱で何らかの特徴的な変化を反映している可能 性を示唆している.いずれにしても, G. truncatulinoides の左巻き個体が優勢な層準の下限 (11.5 万年前) とその 上限 $(5$ 万年前) は，北西太平洋域の過去 30 万年間に おいて最も若い基準面として有効である.
\end{abstract}

* 熊本大学理学部地球科学教室 $\uparrow 860$ 熊本市黒髪 2-39-1. 


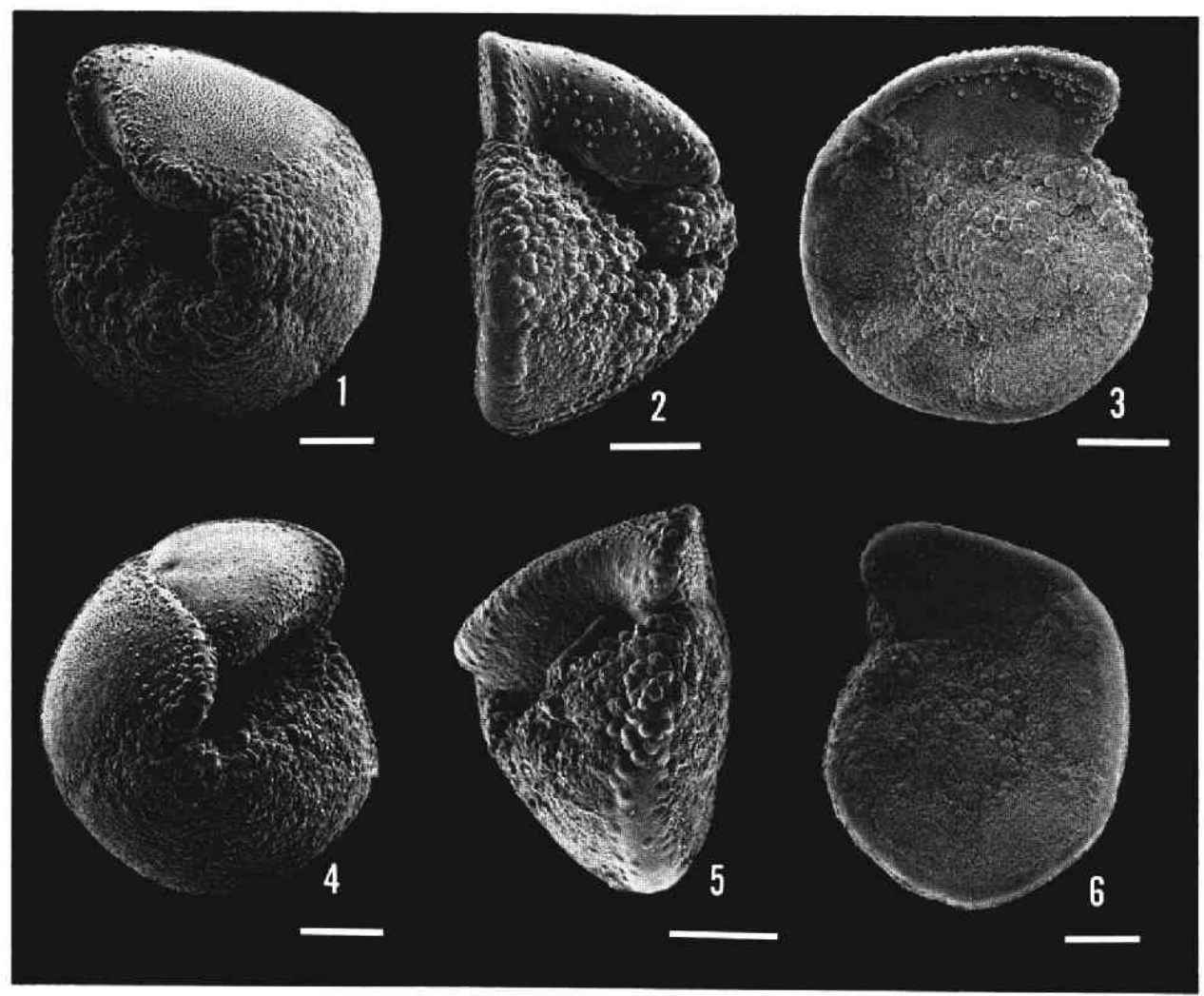

Plate 1 (All scale bars $=100 \mu \mathrm{m})$

1, 2, 3 : Right-coiling Globorotalia truncatulinoides (d'Orbigny) from $46.1 \sim 48.4 \mathrm{~cm}$ of KH92-1 2PC. 1. umbilical view, 2. side view, 3. spiral view

4, 5, 6 : Left-coiling Globorotalia truncatulinoides (d'Orbigny).

4. umbilical view, from $129.1 \sim 131.4 \mathrm{~cm}$ of KH92-1 $2 \mathrm{PC}$

5. side view, from $104 \sim 106 \mathrm{~cm}$ of RN89-PC3

6. spiral view, from $129.1 \sim 131.4 \mathrm{~cm}$ of $\mathrm{KH} 92-12 \mathrm{PC}$ 